\title{
En uvanlig årsak til akutt luftveisobstruksjon
}
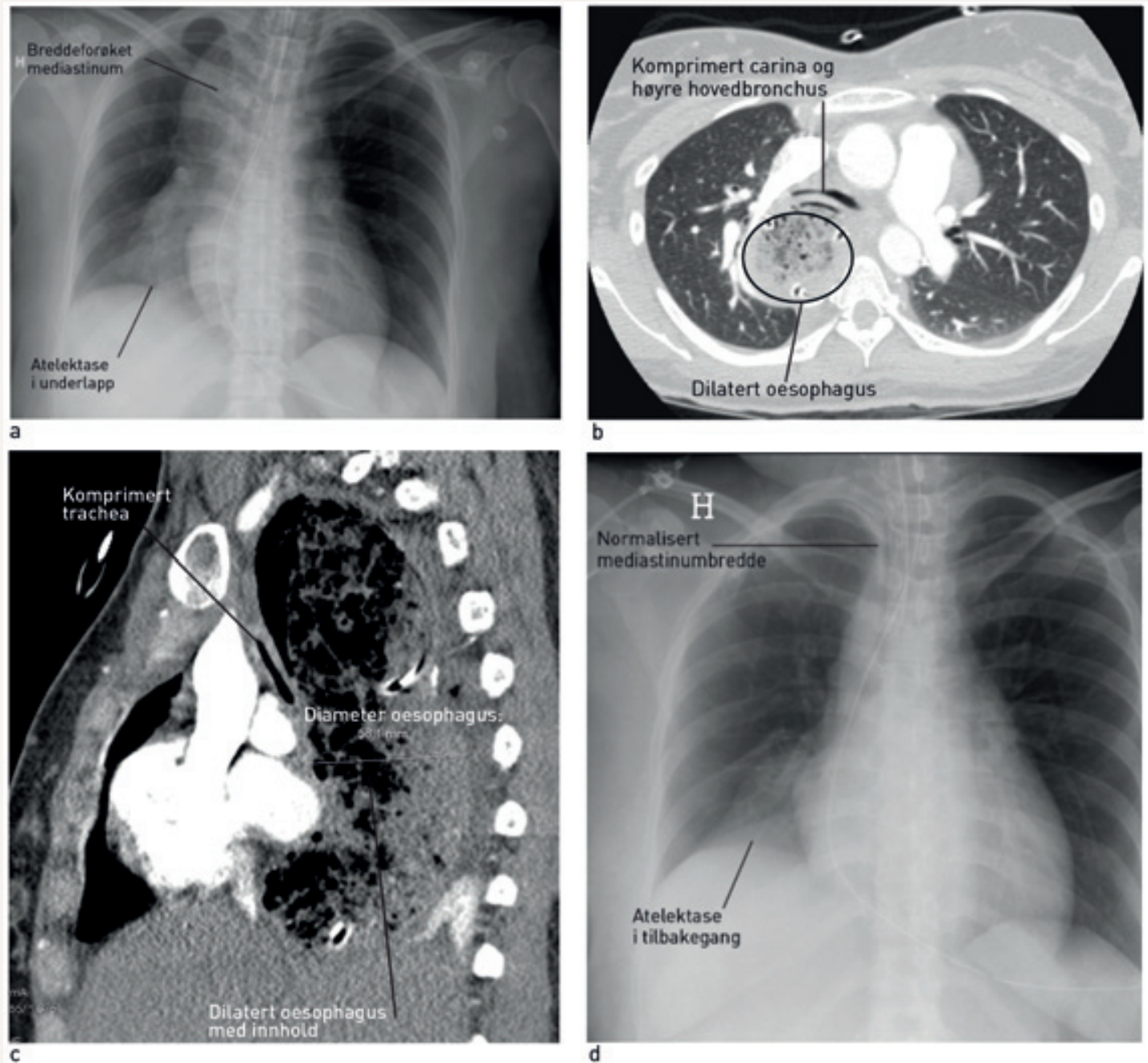

En kvinne i 30-årene ble innlagt på sykehus for fødsel. De tre siste årene hadde hun hatt tiltakende dysfagi av væske og fast føde, dyspné i forbindelse med måltider og vanskeligheter med å rape. Fødselen forløp ukomplisert, men to dager post partum fikk hun akutt respirasjonsbesvær etter frokost og måtte intuberes. Røntgen thorax front viste økt bredde på øvre mediastinum og høyresidig underlappsatelektase (fig 1a). Videre utredning med CT thorax viste betydelig dilatasjon av hele oesophagus og at denne komprimerte både trachea og høyre hovedbronchus (fig 1b, fig 1c).

Gastroskopi viste dilatert oesophagus med matrester, men ingen strikturer eller slimhinneforandringer. På mistanke om akalasi ble det umiddelbart foretatt blokking av nedre oesophagussfinkter med ballong. Kontrollrøntgen samme kveld viste normalisert mediastinumbredde og delvis tilbakegang av underlappsatelektasen (fig 1d). Ved kontroll to uker senere var pasienten symptomfri, og oesophagusmanometri viste funn forenlig med akalasi.

Luftveisobstruksjon som følge av akalasi forekommer ekstremt sjelden og antas å være forårsaket av at luft samler seg i oesophagus og komprimerer luftveiene. Tilstanden er potensielt livstruende og krever rask og adekvat behandling.

\section{Vemund Paulsen}

vemund.paulsen@oslo-universitetssykehus.no Avdeling for organtransplantasjon, fordøyelsesog nyresykdommer

\section{Trygve Syversveen}

Avdeling for radiologi og nukleærmedisin

Kjell Kett

Avdeling for organtransplantasjon, fordøyelsesog nyresykdommer

Oslo universitetssykehus, Rikshospitalet 0027 Oslo

Pasienten har gitt tillatelse til at artikkelen blir publisert.

Oppgitte interessekonflikter: Ingen

Manuskriptet ble mottatt 14.10. 2010 og godkjent 21.10. 2010. Medisinsk redaktør Michael Bretthauer. 